\title{
Viral Reflections: Placing China in Global Health Histories
}

\section{MARY AUGUSTA BRAZELTON (1)}

Public health in China has become a global concern as a consequence of the outbreak and worldwide spread of COVID-19. This article examines the historical place of China in international and global health. Contrary to prevalent narratives in the history of medicine, China and Chinese historical actors played key roles in this field throughout the twentieth century. Several episodes illustrate this argument: the Qing organization of the International Plague Conference in 1911; the role of China in the work of the interwar League of Nations Health Organization and postwar establishment of the World Health Organization; Cold War medical diplomacy; and Chinese models of primary health care during the 1970s. These case studies together show that Chinese physicians and administrators helped shape concepts and practices of "global health" even before that term rose to prominence in the 1990s, and current events are best understood in the context of this history.

Keywords: global health, international health, medical diplomacy, twentieth-century China, primary health care, World Health Organization, plague, COVID-19

$\mathrm{T}$ HERE ARE FEW NARRATIVES as compelling, or as contested, as the beginning of an epidemic. Where did it come from? How did it spread? The history of medicine suggests that these questions are usually impossible to answer definitively, and often only reinforce harmful stigmas and misconceptions. ${ }^{1}$ Nonetheless, the origin of the novel coronavirus SARS-CoV-2 has attracted a wealth of attention and speculation from scientists, government officials, and media commentators. The exact means of zoonotic transmission remain unclear, but there is a broad consensus that the condition caused by the virus, known as COVID-19, first appeared in Wuhan in late 2019. The role attributed to the government of the People's Republic of China (PRC) in responding to the outbreak has varied greatly, ranging from accusations of negligence in allowing the virus to spread outside its borders to assertions of its success in controlling the outbreak through extensive quarantine and rapid resource mobilization.

Distinct cultures and politics of science and medicine have contributed to strikingly variable national responses to this global crisis. In South Korea and Taiwan, epidemiologists have employed contact tracing, border surveillance, and increased dissemination of face masks. In the United States, federal authorities imposed barriers to early diagnostic

Mary Augusta Brazelton (mab94@cam.ac.uk) is University Lecturer in Global Studies of Science, Technology, and Medicine in the Department of History and Philosophy of Science at Cambridge University.

${ }^{1}$ Richard A. McKay, Patient Zero and the Making of the AIDS Epidemic (Chicago: University of Chicago Press, 2017). 
testing, and President Donald Trump promoted the drug hydroxychloroquine despite a lack of evidence for its therapeutic efficacy. Swedish officials have articulated the concept of herd immunity, in contrast to standard epidemiological usage, as a means by which the majority of a population might gain immunity to COVID-19 by contracting it. In each case, the groups and individuals involved have tended to claim an objectivity that is itself historically contingent and unstable. ${ }^{2}$

Across this spectrum of responses, the significance of public health systems in China remains constant-yet also unclear. If the city of Wuhan played the part of a "sentinel post," 3 providing early warning of the crisis, then what responsibility lay with the Chinese government to inform other polities, and when? How have data and experience from Wuhan informed transnational efforts to trace and treat cases of COVID-19? What conditions led to the virus escaping the borders of the PRC? These questions expose the ways in which public and global health are — and have been — far from neutral and objective fields of inquiry, but are instead deeply shaped by political, social, and cultural concerns.

This article seeks to provide historical context for China's place in that contested field. Contrary to prevalent narratives in the history of medicine, China and Chinese historical actors have played key roles in international and global health throughout the twentieth century. Several episodes will illustrate this argument: the Qing dynasty's organization of an International Plague Conference in 1911 following an outbreak of pneumonic plague; the prominent place of the Republic of China (ROC) in the work of the interwar League of Nations Health Organization; the role of Chinese diplomats in the establishment of the World Health Organization (WHO); Cold War medical diplomacy; and Chinese models of primary health care in international health during the 1970s.

These case studies together show that China, and the diverse peoples associated with this polity, played a significant role in shaping "global health" even before that term rose to prominence in the 1990s. Yet the Sinophone world continues to occupy unjustifiably peripheral territory in recent histories of the subject. During this period, the polity known as "China" underwent dramatic political and social transformation: from the last years of imperial rule to a Republic marked by regional warlordism, the consolidation of power by the Nationalist Party after 1927, and the establishment of the PRC in 1949 under the Chinese Communist Party. Even as what constituted "China" changed, so, too, did concepts of public and international health take on new meaning; historians have called attention to the origins of international health in colonial medicine and traced shifts from "international" to "global" health in terms of fluctuating power alliances that promoted transnational integration over the twentieth century. Yet even as it has reflected these important changes, the historiography of such "interventions into the lives of other peoples" has predominantly focused on the work of the WHO and Euro-American nongovernmental organizations as a manifestation of Western powers' efforts to cultivate soft power and resist the global spread of communism. ${ }^{4}$

\footnotetext{
${ }^{2}$ Lorraine Daston and Peter Galison, Objectivity (New York: Zone Books, 2007), 17.

${ }^{3}$ Frédéric Keck, Avian Reservoirs: Virus Hunters and Birdwatchers in Chinese Sentinel Posts (Durham, N.C.: Duke University Press, 2020), 81-87.

${ }^{4}$ Theodore M. Brown, Marcos Cueto, and Elizabeth Fee, "The World Health Organization and the Transition from 'International' to 'Global' Public Health," American Journal of Public Health 96, no. 1 (2006): 62-72; Marcos Cueto, Theodore M. Brown, and Elizabeth Fee, The World Health
} 
China features in these narratives as a site of occasional interest-for instance, insofar as its "barefoot doctor" program offered useful examples for rural health projects in the 1970s, or the implementation of its one-child policy in the 1980s suggested an extreme manifestation of global discourses of population control. Within modern Chinese history, by contrast, a number of recent works have demonstrated that medicine and public health fundamentally shaped the making of modern China. ${ }^{5}$ Studies of medicine and health in the Republican era, as well as the early PRC, have immensely enriched our understanding of these processes. In the following account, I seek to demonstrate the significance of this work to global narratives.

\section{Republican Fever Dreams: Early Twentieth-Century Epidemic Crises and}

\section{RESPONSES}

At the turn of the twentieth century, the Qing dynasty figured in transnational sanitary discourses primarily as a dangerous zone harboring deadly infectious diseases. These dark visions seemed to manifest in full in the winter of 1910-11, when pneumonic plague stalked the landscape of Manchuria. This epidemic exposed geopolitical vulnerabilities of the ailing Qing, beset by agents of Russian and Japanese empires seeking to use epidemic prevention as a means to expand influence in northeast China. ${ }^{6} \mathrm{Hu}$ Cheng has noted that the perceived need to protect sovereignty motivated the Qing to adopt harsh methods of quarantine and surveillance. ${ }^{7}$ Central to these accounts is the work of Wu Liande, the Penang-born, Cambridge-trained physician whose interventions asserted the authority of Euro-American biomedicine in China and led to the establishment of the North Manchurian Plague Prevention Service. ${ }^{8}$

Organization: A History (Cambridge: Cambridge University Press, 2019); Randall M. Packard, A History of Global Health: Interventions into the Lives of Other Peoples (Baltimore: Johns Hopkins University Press, 2016).

${ }^{5}$ Bridie Andrews, The Making of Modern Chinese Medicine, 1850-1960 (Vancouver: University of British Columbia Press, 2014); Sean Hsiang-lin Lei, Neither Donkey nor Horse: Medicine in the Struggle over China's Modernity (Chicago: University of Chicago Press, 2014); Angela Ki Che Leung and Charlotte Furth, eds., Health and Hygiene in Chinese East Asia: Policies and Publics in the Long Twentieth Century (Durham, N.C.: Duke University Press, 2010); Ruth Rogaski, Hygienic Modernity: Meanings of Health and Disease in Treaty-Port China (Berkeley: University of California Press, 2004); Yu Xinzhong, ed., Qing yilai de jibing, yiliao he weisheng: yi shehui wenhua shi wei shijiao de tansuo [Disease, medicine, and hygiene since the Qing: An exploration from the perspective of sociocultural history] (Beijing: Sanlian shudian, 2009).

${ }^{6}$ Mark Gamsa, "The Epidemic of Pneumonic Plague in Manchuria, 1910-1911," Past \& Present, no. 190 (2006): 147-83; Christos Lynteris, "Epidemics as Events and as Crises: Comparing Two Plague Outbreaks in Manchuria (1910-11 and 1920-21)," Cambridge Journal of Anthropology 32, no. 1 (2014): 62-76; William C. Summers, The Great Manchurian Plague of 1910-11: The Geopolitics of an Epidemic Disease (New Haven, Conn.: Yale University Press, 2012).

${ }^{7} \mathrm{Hu}$ Cheng, "Dongbei diqu fei shuyi manyan qijian de zhuquan zhi zheng (1910.11-1911.4)" [The competition over sovereign rights during the spread of pneumonic plague in Manchuria (November 1910-April 1911)], in Zhongguo shehui lishi pinglun, di jiu juan [Discussion of the social history of China, vol. 9], ed. Chang Jianhua (Tianjin: Tianjin guji chubanshe, 2008), 225-29.

${ }^{8}$ Lei, Neither Donkey nor Horse, 21-44. 
The outbreak also had consequences for international health. At this time, "international health" consisted largely of attempting to prevent epidemics, especially cholera, from crossing national and imperial borders; a series of International Sanitary Conferences had been convened for this purpose since the 1850s. When the Qing court called for an International Plague Conference to be held at Shenyang (then Mukden) in April 1911, it signaled Chinese ambitions to participate actively in transnational medical networks at a moment when a growing spirit of medical internationalism had increased the significance of such networks for the discussion of epidemic control. ${ }^{9}$ In his welcoming address, Viceroy Xi Liang articulated the goal of bilateral exchange: "I sincerely hope that your deliberations during the next few weeks will result in the saving of human lives, not only of this country but of others also, should this terrible disease unfortunately break out elsewhere."10 Delegates came from across Europe, North America, Russia, and Japan; most requested laboratory space to conduct research and spent a month studying and debating questions of the disease's pathology and transmission. The conference thus asserted China as a place where epidemiological research, as well as epidemic outbreaks, could carry global significance. Robert Perrins describes it as "one of the first major international gatherings that visibly promoted a global perspective on human healthcare."11

The International Plague Conference provided extensive opportunities to discuss research and policy questions of plague control. In this function, it created professional opportunities for attendees. For Wu Liande, chairing the event offered a chance to consolidate his status as a leading researcher and administrator of Western medicine in China to global audiences. The American delegate Richard P. Strong was at the time a colonial medical officer stationed in the Philippines; his participation in the conference, and role in compiling its summary report, facilitated his rise in the field of tropical medicine. ${ }^{12}$ Because outbreaks of pneumonic plague with human-to-human transmission are rare, research presented at the conference was of lasting significance. ${ }^{13}$ The International Plague Conference thus provided a foundation for Chinese states' participation inand contributions to- - transnational epidemiological cooperation.

Subsequent decades saw the rise of new organizations that projected geopolitical power through medical diplomacy, especially after the influenza pandemic of 1918. The Rockefeller Foundation's interventions to export American tropical medicine and

\footnotetext{
${ }^{9}$ Knab, "Plague Times," 88, 99.

${ }^{10}$ Richard P. Strong, Report of the International Plague Conference Held at Mukden, April, 1911 (Manila: Bureau of Printing, 1912), 4.

${ }^{11}$ Robert J. Perrins, "Debating Disease: The History of the Manchurian International Plague Conference of April 1911" (paper presented at the XIV International Economic History Congress, Session 46, Disease and Environmental Change in Modern Asia, Helsinki, Finland, August 25, 2006), http://www.helsinki.fi/iehc2006/papers2/Perrins (accessed July 10, 2020).

${ }^{12}$ Eli Chernin, "Richard Pearson Strong and the Manchurian Epidemic of Pneumonic Plague, 1910-1911," Journal of the History of Medicine and Allied Sciences 44, no. 3 (1989): 319.

${ }^{13}$ S. M. Babin, "Using Syndromic Surveillance Systems to Detect Pneumonic Plague," Epidemiology and Infection 138, no. 1 (2010): 4; Jacob L. Kool, "Risk of Person-to-Person Transmission of Pneumonic Plague," Clinical Infectious Diseases 40, no. 8 (2005): 1167-70.
} 
implement top-down technical methods for disease prevention, especially through its International Health Division, have been well documented. ${ }^{14}$ By 1933 it had invested more money in China than any country outside the United States, most notably in the establishment of Peking Union Medical College-the only school of medicine the foundation ever established and administrated directly. A separate program implemented between 1935 and 1937 in north China represented an early effort to integrate public health into rural development. ${ }^{15}$

A key agency in the interwar geopolitical order, the League of Nations, took on international public health as a major function. The goal of establishing hygienic infrastructure in China helped shape the agenda of the League of Nations Health Organization (LNHO) from its formal establishment in 1924 through its disbanding in 1946. One of its earliest projects was the establishment of a Far Eastern Bureau in Singapore; in 1925 the LNHO's medical director, Ludwik Rajchman, traveled to China and subsequently became deeply invested in facilitating the development of public health there. Physician Andrija Štampar's work on behalf of the LNHO as a consultant to the Nationalist government in the early 1930s, especially his advocacy for preventive and social medicine, also played a formative role in the establishment of health administration. ${ }^{16}$

During this period, Rajchman and his colleagues sponsored and oversaw the establishment of a Central Field Health Station in Nanjing. "Above all, it performs a truly pioneering service in rural districts, where the need of its manifold activities is felt more acutely than in many other countries," wrote Rajchman of the station and associated health services. ${ }^{17}$ Iris Borowy has pointed to the significance of this project for testing the ideological goals of the LNHO: namely, to provide "blueprints for national health systems"; to articulate "a comprehensive concept of health, which incorporated medical, political and social responsibilities"; and to use this concept of health as a means of supporting world peace. ${ }^{18}$ Although the LNHO ultimately fell short of its operational goals in China, Chinese experiences shaped its broader approach to medical interventions (and beyond; Rajchman was instrumental in founding UNICEF).

\footnotetext{
${ }^{14}$ Warwick Anderson, Colonial Pathologies: American Tropical Medicine, Race, and Hygiene in the Philippines (Durham, N.C.: Duke University Press, 2006); Anne-Emmanuelle Birn and Elizabeth Fee, "The Art of Medicine: The Rockefeller Foundation and the International Health Agenda," The Lancet 381, no. 9878 (2013): 1618-19; John Farley, To Cast Out Disease: A History of the International Health Division of the Rockefeller Foundation (Oxford: Oxford University Press, 2003); Steven Palmer, Launching Global Health: The Caribbean Odyssey of the Rockefeller Foundation (Ann Arbor: University of Michigan Press, 2010).

${ }^{15}$ Socrates Litsios, "Selskar Gunn and China: The Rockefeller Foundation's 'Other' Approach to Public Health," Bulletin of the History of Medicine 79, no. 2 (2005): 296.

${ }^{16} \mathrm{Su}$ Jingjing and Zhang Daqing, "Guoji weisheng lilun yu shijian zai zhongguo de tuidong zhe andeliya sidanba” [Andrija Štampar: A theorist and practitioner of international health in China]. Kexue wenhua pinglun 15, no. 6 (2018): 81-90.

${ }^{17}$ Ludwik Rajchman, League of Nations Council Committee on Technical Cooperation between the League of Nations and China: Report of the Technical Agent of the Council on His Mission in China, from the Date of His Appointment until April 1st, 1934, official no. C.157.M.66.1934 (Geneva: Series of League of Nations Publications, General, 1934), 58.

${ }^{18}$ Iris Borowy, Coming to Terms with World Health: The League of Nations Health Organisation, 1921-1946 (Frankfurt am Main: Peter Lang, 2009), 312.
} 
By the eruption of the Second World War, China's notoriety as a place that was both vulnerable to epidemic outbreak and in need of medical infrastructure made it central to considerations of transnational epidemic control and intervention. Yet the story was not one of abject exposure to disease and death. Even during the turmoil of the Second SinoJapanese War, researchers and administrators contributed their voices and work to discourses that framed China as an experimental space: ${ }^{19}$ one where epidemics might take thousands of lives in the course of one bitter winter, but also where the causative agents of those outbreaks might be identified and new public health projects could be developed using a range of cooperative alliances.

\section{Medical Diplomacy in the Postwar Order}

In 1945, Szeming Sze (Shi Siming, 1908-98) played a key role in the establishment of the WHO. The time was April 1945; the event was the United Nations (UN) Conference on International Organization in San Francisco. Sze, the son of the statesman Alfred Sao-ke Sze (Shi Zhaoji, 1877-1958) and a Cambridge-trained physician, was the secretary of the chief delegate from China, T. V. Soong. Unaware that the US and UK delegations had privately agreed that health should not appear on the meeting's agenda, Sze and two other delegates, Norway's Karl Evang and Brazil's Geraldo De Paula Souza, agreed that an international health organization should be established. "Luckily, securing the approval of the Chinese delegation for initiating the proposal was rather easily accomplished, as I had the ear of the chief of the delegation," Sze later noted. ${ }^{20}$ Sze subsequently wrote a text advocating for such an agency, which he presented with Souza as a declaration that met with enthusiastic approval. Sze then coordinated meetings for a preparatory committee to establish what became known as the WHO. In January 1946, the Chinese delegation to the UN Economic and Social Council called for a conference of UN member governments to establish a new health organization. Sze oversaw the passage of subsequent proposals through the administrative machinery of the UN and successfully argued for the new agency to be named the World Health Organization. ${ }^{21}$

Although Chinese diplomats were conjuring up a new world of international health, China itself remained mired in military conflict. As Sze made his proposals in San Francisco, civil war was erupting between China's Nationalist and Communist Parties. After the establishment of the People's Republic on the mainland in 1949, Chiang Kai-shek's Republican government-now on Taiwan-continued to represent China in the WHO, UN, and other organizations of international governance. The resulting bifurcation of Chinese medical administrations would have a major impact on international health.

\footnotetext{
${ }^{19}$ Nicole Elizabeth Barnes, Intimate Communities: Wartime Healthcare and the Birth of Modern China, 1937-1945 (Oakland: University of California Press, 2018); John Robertson Watt, Saving Lives in Wartime China: How Medical Reformers Built Modern Healthcare Systems amid War and Epidemics (Leiden: Brill, 2014).

${ }^{20}$ Szeming Sze, The Origins of the World Health Organization: A Personal Memoir, 1945-48 (Boca Raton, Fla.: L.I.S.Z. Publications, 1982), 3.

${ }^{21}$ Cueto, Brown, and Fee, The World Health Organization, 37-39; Sze, The Origins of the World Health Organization, 1-17.
} 
Although narratives of global health have focused on the Western world and its often neocolonial use of medical interventions to support Cold War objectives, the socialist side of the story has received less attention. Recent work has drawn attention to the ways in which the Soviet Union and allies established networks of health cooperation and intervention. ${ }^{22}$ Gao Xi has demonstrated the significance of Chinese engagement with Soviet medical aid in the early 1950s. ${ }^{23}$ Domestically, the PRC invested in public health programs, notably schemes of training paraprofessional health workers - eventually called "barefoot doctors" - in Chinese and Western traditions to support rural health, as well as mass immunization against infectious diseases and schistosomiasis control.

In the 1960s and 1970s, Chinese health officials also promoted their work abroad as a matter of foreign policy. The PRC used medical diplomacy to compete for influence and acknowledgment with the ROC on Taiwan, focusing their efforts on the "nonaligned" world. Southeast Asia, Latin America, and especially Africa became important battlegrounds for both the governments that claimed authority over one China. In the PRC, these efforts largely focused on Africa, where diplomats emphasized shared experiences of anticolonial conflict. Medical aid most often manifested on the ground in teams of physicians, supplies, educational materials, and occasionally student-exchange programs. These programs promoted a distinctively Chinese form of rural health. For instance, starting in 1964, physicians helped establish a health program in the United Republic of Tanzania that drew on the barefoot doctor model and included training medical personnel, building a medical laboratory, administering hospitals, and conducting health demonstrations in villages. ${ }^{24}$ A People's Daily report capitalized on these programs' symbolic meaning for domestic audiences: "Chinese medical personnel often braved the scorching sun and torrential rain, traversed mountains and forests, and crossed rapids to provide medical care to villages . . . When the Tanzanian people saw the spirit of the Chinese medical personnel to sincerely serve them, they were very moved." 25 PRC medical diplomacy continued throughout the Cultural Revolution and the postsocialist transition. From the early 1960s to the early 2000s, over fifteen thousand Chinese medical workers traveled to forty-seven African nations as part of cooperative programs. ${ }^{26}$

Across the Taiwan Strait, similar strategies of medical diplomacy took shape, albeit in a radically different geopolitical context; the ROC oversaw the replacement of Japanese

\footnotetext{
${ }^{22}$ Dóra Vargha, Polio across the Iron Curtain: Hungary's Cold War with an Epidemic (Cambridge: Cambridge University Press, 2018).

${ }^{23} \mathrm{Gao} \mathrm{Xi}$, "Foreign Models of Medicine in Twentieth-Century China," in Medical Transitions in Twentieth-Century China, eds. Bridie Andrews and Mary Brown Bullock (Bloomington and Indianapolis: Indiana University Press, 2014), 196-211.

${ }^{24}$ Alicia N. Altorfer-Ong, "Old Comrades and New Brothers: A Historical Re-Examination of the Sino-Zanzibari and Sino-Tanzanian Bilateral Relationships in the 1960s" (PhD diss., London School of Economics and Political Science, 2014), 241-73.

25، Nimen shi Mao zhuxi pailai de hao yisheng’-ji Zhongguo yiliao dui zai Tansangniya nongcun xunhui yiliao" [You are good doctors sent by Mao: Record of a Chinese medical team in rural Tanzania], Renmin ribao, March 31, 1969, 6.

${ }^{26}$ Jeremy Youde, "China's Health Diplomacy in Africa," China: An International Journal 8, no. 1 (2010): 159.
} 
colonial medicine on Taiwan with American standards and professional organization. ${ }^{27}$ Drawing on American financial support, ROC diplomats also actively participated in efforts to contain mainland Chinese influence in the so-called developing world, often focusing on the same African territories that PRC efforts in medical diplomacy targeted. In 1959, the ROC announced an International Cooperation Program that provided agricultural assistance, including medical programs, to newly decolonized states in Africa. The Ministry of Foreign Affairs launched this program in 1961 with the dispatch of a team to Liberia; it ultimately sent 922 experts to Africa and brought over 400 Africans to Taiwan during the 1960 s and 1970 s. $^{28}$

These initiatives faltered as Taiwan encountered difficulties on the global political scene. In 1971, following the rapprochement of the PRC and the United States, the former rejoined the $\mathrm{UN}$ as the sole representative of China, resulting in the expulsion of the ROC. As a UN affiliate, the WHO followed suit, welcoming the PRC in 1972 and ejecting the ROC. With the exception of a brief period from 2009 to 2016 in which the ROC was permitted to attend the World Health Assembly as an observer, the ROC has since been largely excluded from international health policymaking. The current absence of Taiwanese models and precedents from contemporary discussions of COVID-19 in global health organizations should be understood in this historical context.

\section{The Gospel of Primary Health Care: Making a Chinese Model for the World}

From its new vantage point as a member of the WHO, throughout the 1970s, the PRC actively promoted its system of rural medical care as a model for the future of global health governance. Although the policy impact of these efforts was short-lived, their success lay in again bringing Chinese voices and actors to the forefront of international health. Officials stressed the good health of China to demonstrate not only medical competence, but also their ability to lead medical administration on a global stage.

The formal readmission of the PRC to the WHO provided an opportunity to challenge prevailing idealizations of the practices and standards of Euro-American professional medicine. ${ }^{29}$ Over the 1970 s, Su Jingjing suggests, "exchanges in medicine and public health became a means of understanding China's governmental achievements, as well as its social and economic situation." 30 The Ministry of Health invited delegations

\footnotetext{
${ }^{27}$ Michael Shiyung Liu, "From Japanese Colonial Medicine to American-Standard Medicine in Taiwan: A Case Study of the Transition in the Medical Profession and Practices in East Asia," in Science, Public Health and the State in Modern Asia, eds. Liping Bu, Darwin Stapleton, and Ka-che Yip (Abingdon: Routledge, 2012), 161-62.

${ }^{28}$ Altorfer-Ong, "Old Comrades and New Brothers," 234-35; Chiao Chiao Hsieh, Strategy for Survival: The Foreign Policy and External Relations of the Republic of China on Taiwan, 1949-79 (London: Sherwood Press, 1985), 307-11.

${ }^{29}$ Sung Lee, "WHO and the Developing World: The Contest for Ideology," in Western Medicine as Contested Knowledge, eds. Andrew Cunningham and Bridie Andrews (Manchester: Manchester University Press, 1997), 24-25.

${ }^{30}$ Su Jingjing, "Zhongguo yu shijie weisheng zuzhi hezuo zhong de shenfen zhuanbian: 1949-1978" [The commencement of multilateral health diplomacy of People's Republic of China], Zhongguo keji shi zazhi 39, no. 1 (2018): 78.
} 
of researchers and physicians from Europe and North America to visit the PRC and observe firsthand its successes in medical administration. Visitors returned with glowing reports of the integration of Chinese and Western medical traditions via acupuncture anesthesia, barefoot doctors, and other programs, having been shown carefully curated sites and clinics. ${ }^{31}$

These good impressions translated into admiration for the systems of rural health that the PRC enshrined for foreign audiences. Over the 1970s, these programs presented a model for emergent ideals of "primary health care," which combined strong local leadership, grassroots labor, mass education, and affordable preventive work-distinctive elements of the health programs deployed in projects of medical diplomacy in previous decades. The organization and administration of these programs drew particular attention. For instance, Philip Lee, professor of social medicine at the University of California, San Francisco, reported after a 1973 trip to the PRC that two aspects of its medical policy offered lessons for Americans: "the priority accorded public health programs and a clear set of guiding principles." 32 The Chinese case ultimately articulated a vision for public health that attracted worldwide consensus. A 2008 WHO publication claims that "China's barefoot doctors were a major inspiration to the primary health care movement," which culminated in the Alma-Ata Declaration of 1978, a resolution that set forth primary health care as a major new direction for the WHO. ${ }^{33}$

Although Chinese models thus provided a basis for one of the most striking shifts in global health policy of the twentieth century, recent studies suggest that these models emerged from a more complex medical environment. The barefoot doctors, widely praised for combining medical traditions, actually frequently embraced practices identified with Western medicine. ${ }^{34}$ The model of health care that became enshrined in Western discourses of global health contrasted with the practices that actually made anti-schistosomiasis campaigns successful. ${ }^{35}$ And the successes of epidemic control that legitimized this model were built on familiar, largely top-down strategies of mass immunization. ${ }^{36}$ Against this background, health officials articulated strengths of medical administration, bound up with ideals of primary health care and building upon experiences of socialist internationalism, in order to assert capability and authority in world health governance.

\footnotetext{
${ }^{31}$ Zhou Xun, "From China's 'Barefoot Doctor' to Alma Ata: The Primary Health Care Movement in the Long 1970s," in China, Hong Kong, and the Long 1970s: Global Perspectives, eds. Priscilla Roberts and Odd Arne Westad (Cham, Switzerland: Palgrave Macmillan, 2017), 140-44.

${ }^{32}$ Philip R. Lee, "Medicine and Public Health in the People's Republic of China," Western Journal of Medicine 120, no. 5 (1974): 432.

${ }^{33}$ Cui Weiyuan, "China's Village Doctors Take Great Strides," Bulletin of the World Health Organizations 86, no. 12 (2008): 914.

${ }^{34}$ Fang Xiaoping, Barefoot Doctors and Western Medicine in China (Rochester, N.Y.: University of Rochester Press, 2012), 3.

${ }^{35}$ Miriam Gross, Farewell to the God of Plague: Chairman Mao's Campaign to Deworm China (Oakland: University of California Press, 2016), 237-38.

${ }^{36}$ Mary Augusta Brazelton, Mass Vaccination: Citizens' Bodies and State Power in Modern China (Ithaca, N.Y.: Cornell University Press, 2019), 163.
} 


\section{ConClusions}

Chinese dreams of health for all became global ambitions at the end of the 1970s, but they were never fully realized. In international health, the 1980s saw the emergence of "selective primary health care," which eschewed sweeping reforms in favor of limited interventions that largely continued traditional focuses on targeted, technological approaches such as immunization. ${ }^{37}$ Even in the PRC, economic, social, and political transformations in the 1980s and 1990s led to the disintegration of support for rural health in many provinces. ${ }^{38}$ The 2003 eruption of a novel coronavirus, SARS-CoV-1, lay bare structural shortcomings in the health systems of the postsocialist PRC. The episode provoked a major reformulation of epidemiology in China, largely designed to avert the possibility of a similar scenario reemerging. ${ }^{39}$ And yet, seventeen years later, the world faces a second novel coronavirus, even more fearsome.

I will not attempt to predict what COVID-19 will leave in its wake-or even that there will ever really be an end. In response to the AIDS epidemic of the 1980s, the historian of medicine Charles Rosenberg articulated a dramaturgy of epidemics that sets out discrete stages of revelation, explanation, response, and memory. ${ }^{40}$ Yet recent scholarship - and current experience-suggests that we should resist such simple narratives. Epidemics leave exposed in their wake personal grief, scientific controversies, and institutional failings, even as their disruption of existing social, cultural, and political systems offers the potential for productive transformation. ${ }^{41}$ Organizations that claim neutral coordination on the basis of medical science in fact carry forward historic social, cultural, and political entanglements that complicate efforts to coordinate pandemic responses. Acknowledging the history of those relationships may help provide a means of transcending them.

\footnotetext{
${ }^{37}$ Cueto, Brown, and Fee, The World Health Organization, 180-98.

${ }^{38}$ Jane Duckett, The Chinese State's Retreat from Health: Policy and the Politics of Retrenchment Abingdon: Routledge, 2011), 3-7.

${ }^{39}$ Katherine A. Mason, Infectious Change: Reinventing Chinese Public Health after an Epidemic (Stanford, Calif.: Stanford University Press, 2016), 3.

${ }^{40}$ Charles Rosenberg, "What Is an Epidemic? AIDS in Historical Perspective," Daedalus 118, no. 2 (1989): 3-8.

${ }^{41}$ Dóra Vargha, "After the End of Disease: Rethinking the Epidemic Narrative," Somatosphere, May 17, 2016, http://somatosphere.net/2016/after-the-end-of-disease-rethinking-the-epidemicnarrative.html/ (accessed July 10, 2020).
} 